\title{
IAMJ
}

INTERNATIONAL

AYURVEDIC

MEDICAL JOURNAL

do) $\partial$ (요

Research Article

ISSN: 2320-5091

Impact Factor: 6.719

\section{COMPARATIVE CLINICAL STUDY OF KUMARIKA VATI AND MEFENAMIC ACID IN UDAVARTINI YONIVYAPAD (SPASMODIC DYSMENORRHEA)}

\author{
Rashmi Verma ${ }^{1}$,Supriya $M^{2}$, Shobha Mattur ${ }^{3}$ \\ PG Scholar ${ }^{1,}$ Professor $^{2}$, Assistant Professor $^{3}$ \\ Department of Prasooti Tantra \& Stree Roga, Sri Jagadguru Gavishiddheshwar Ayurvedic Medical College, \\ Koppal, Karnataka - 583231, India
}

Corresponding Author: rashuverma25@gmail.com

https://doi.org/10.46607/iamj0309122021

(Published Online: December 2021)

Open Access

(C) International Ayurvedic Medical Journal, India

Article Received: 17/10//2021 - Peer Reviewed: 30/12/2021 - Accepted for Publication 31/10/2021

\section{Check for updates}

\begin{abstract}
Menstruation is a normal physiological process when it is accompanied by pain is called Dysmenorrhea. It is one of the commonest gynaecological complaints. Dysmenorrhea is painful menstruation, which is the pratyatma laxana of Udavartini yoni vyapad i.e., spasmodic dysmenorrhea. It is a common cause of distress in women. Here the main reason for pain is the vitiation of vata dosha (apana vata), viloma/pratiloma gati leading to vedna yukta artava munchan and to manage this pratiloma vata, one needs to use drugs that have anulomana properties and vedna samak. Kumarika vati is used as vedana shamaka aushadha to give symptomatic relief. Hence the topic was selected for the study. Objectives: To compare the effect of Kumarika Vati with Mefenamic Acid in the management of Udavartini Yonivyapad (Spasmodic Dysmenorrhea). Materials \& Methods: 20 patients of Group A were treated with Kumarika Vati, a dose of $250 \mathrm{mg}$ BD 5 days before menstruation \& 5 days during menstruation. 20 patients of Group B were treated with a Mefenamic Acid dose of 250mg BD for 3 days during menstruation. Result: The data of both groups were collected according to the objective and subjective parameters and analyzed using the most appropriate statistical test (repeated measures of ANOVA test and Mann -Whitney U test). The efficacy is statically significant within the group at $\mathrm{P}<0.001$ and statistically insignificant between the group at
\end{abstract}


$\mathrm{P}>0.05$ among all the parameters. Interpretation and Conclusion: On comparison of Kumarika Vati with Mefenamic acid both have equal effectiveness in relieving the pain intensity, pain duration, site of pain, nature of pain and associated complaints.

Keywords: Udavartini Yoni Vyapad, Dysmenorrhea, Kumarika Vati, Mefenamic Acid.

\section{INTRODUCTION}

Ayurveda has always understood the importance of women's health and its role in society which is very clearly delineated in Charaka Samhita. In Ayurveda, a healthy woman is not only seen as a prerequisite for producing a healthy generation but also seen as a driver of social, economic and spiritual change in terms of Dharma, Artha, Kama and Moksha. ${ }^{1}$ In this highly competitive life, women's health suffers a lot owing to the social expectation from them, limited access to health services, limited health literacy, and reproductive burden, physical, mental and financial stresses, making them more susceptible to various gynaecological disorders. Among them, dysmenorrhea is one such commonly reported menstrual disorder. According to WHO, Dysmenorrhea is the most important cause of chronic pelvic pain, and the disease burden of dysmenorrhea is estimated to be greater than any other gynaecological morbidity, in women of reproductive period regardless of age, nationality and economic status. The epidemiology of primary dysmenorrhea is 25 to $90 \%$ among women and adolescents respectably. Studies from India reported the prevalence range between 50 to $87.8 \%$. $^{2}$ Ayurveda must be credited with the first health science which defined the parameters of menstrual health and identified the menstrual disorders along with their aetiology, etiopathogenesis and clinical features in Vimshati Yoni Vyapad. Udavartini Yoni Vyapad is characterized vedana yukta Artava munchan a complaint with spasms and contraction. The vedana yukta Artava munchan, this condition can be easily identified with the clinical entity of dysmenorrheal in modern gynaecological parlance. Clinically it is defined as the painful menstruation of sufficient magnitude to incapacitate day to day activities of a woman. ${ }^{3}$ The clinical picture of the dysmenorrheal include recurrent crampy suprapubic pain which may radiate to the back and thighs occurring just before or during menses and lasting two or three days, pain may radiate into the lower back and thighs and may be associated with nausea, fatigue, bloating and general malaise, nausea vomiting and diarrhoea. ${ }^{4}$ In the present scenario, due to globalization, industrialization, and urbanization there is a rapid transition of a traditional holistic healthy lifestyle to the westernized lifestyle which promotes dietary indiscretion and stressful living leading to a higher prevalence rate of Dysmenorrhea in young adults, especially in 14-30 years of age. Additionally, the present generation of women is giving away the traditional menstrual health promotion practice of Rajaswala Paricharya leading to a higher incidence of menstrual disorders. Conventional western medicine offers the use of NSAID $_{S}$ and Ovulation inhibition with Oral contraceptive pills for the management of these disorders which come with several side effects and play havoc with the women's reproductive health. Ayurveda on the other hand can help in the management of dysmenorrhea more safely and holistically. Many research studies across the globe have identified several plant-based medicines which have analgesic, spasmolytic and anti-inflammatory effects. Kumarika vati is one such formulation explained in Bhaisajya Ratnavali in Yoni vyapad chikitsa. Hence to rule out the efficacy of Kumarika vati in Udavartini Yoni Vyapad, ${ }^{5}$ this study was undertaken.

Material and Method: The present study was a randomized open-labelled control clinical study with Kumarika vati and Mefenamic acid.

Collection and Preparation of Drug: The ingredient of Kumarika vati were obtained from authentic sources and was authenticated by the botanist from the department of Dravyaguna and Rasashastra SJGAMC Koppal and Research centre. Vati of 250 
mg was prepared in the Laboratory of Dravyaguna and Rasashastra SJGAMC Koppal and it was dried in shade \& stored in a glass container. Tab Mefenamic
Acid 250mg (Meftal 250) were purchased from the local Market.

Table 1: Ingredients of Kumarika Vati

\begin{tabular}{|l|l|l|l|l|}
\hline Sl. No & Sanskrit Name & Part Used & Form & Quantity \\
\hline 1 & Kumari & Aloveraghana & Coarse Powder & $50 \mathrm{gm}$ \\
\hline 2 & Ahiphena & Bija(khasakhas) & Coarse Powder & $50 \mathrm{gm}$ \\
\hline 3 & Agastya twak & Twak & Coarse Powder & $50 \mathrm{gm}$ \\
\hline 4 & Kasis & Bhasma & Powder & $50 \mathrm{gm}$ \\
\hline 5 & Vanga & Bhasma & Powder & $50 \mathrm{gm}$ \\
\hline
\end{tabular}

\section{Source of Data:}

Literary Source: All Ayurvedic texts, contemporary Ayurvedic literature, articles and internet sources about the disease and drug were reviewed and documented for the study.

Sample Source: 40 subjects fulfilling the diagnostic criteria concerning age (between age group 14-30 years) irrespective of their religion, caste, race, socioeconomic status was taken from the institution, diagnosed by the Department of Prasuti Tantra and Stree Roga at S.J.G Ayurvedic Medical College \& Hospital, PG Studies \& Research Centre, Koppal, India.

Study Method: It is an open level comparative clinical study 14-the 30-year age group with an assessment before and after clinical study.

Diagnostic Criteria:

- Patients having painful menstruation.

- Patients between the ages of 14 to 30 .

- Patients have regular menstrual cycles.

Inclusion Criteria:

- Patients between the age group of 14 to 30 .

- Patients complaining painful menstruation.

- Patients have a regular menstrual cycle.

- Both married and unmarried.

Exclusion Criteria:

- Patient with fibroid uterus, malignancy, uterine polyps, PID, endometriosis, IUCD etc.

- Disease-related to the urogenital system.

- Patient with systemic disorders like DM, HTN, TUBERCULOSIS.

- Lactating mother.

- Patient on hormonal therapy OCP's.
- Diagnosed case of congenital anomaly of the uterus.

Assessment Criteria:

- Pain Intensity

- Pain Duration

- Site of Pain

- Nature of Pain

- Menstrual Flow Duration

- Associated Complaints

\section{Research Design \& Intervention:}

- Forty subjects who fulfilled criteria were selected and randomized into two equal -Group A and Group B

- The nature of the study was explained to each subject in detail and written consent was taken.

Group A [Trial Group Kumarika Vati] -20 patients were treated with Kumarika Vati. 250mg of $\mathrm{Ku}$ marika vati was given 5 days before menstruation and 5 days during the menstruation in the dose of 1 BD for Two cycles.

Group B [Control Group Mefenamic Acid]-20 patients were treated with Mefenamic acid $250 \mathrm{mg}$ (Tab Meftal 250) one tab BD for 3 days during menstruation for two cycles.

Study Duration: - 3 cycles.

Treatment period: -2 cycles.

Follow Up: During treatment $-1^{\text {st }}$ day each cycle up to 2 consecutive menstrual cycles. $1^{\text {st }}$ day of next consecutive cycle after treatment.

Assessment: Visual analogue scale (VAS) for pain: The Visual analogue scale for pain is a straight line with one end meaning no pain and the other end 
meaning the worst pain imaginable. Here scores are recorded on a $10 \mathrm{~cm}$ horizontal line to indicate their pain intensity, with 0 indicating "no pain" and 10 indicating the "worst pain". ${ }^{6}$

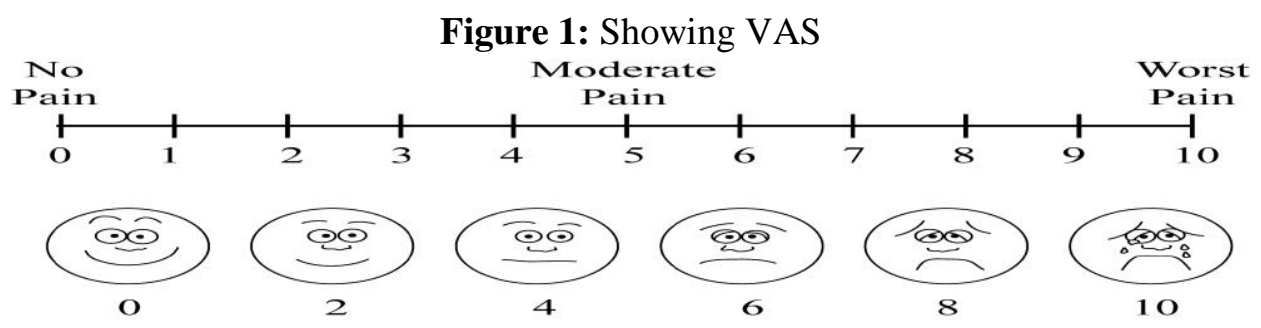

Table 2: Assessment criteria with grading:

\begin{tabular}{|c|c|c|c|c|}
\hline Assessment criteria & Grade 0 & Grade 1 & Grade 2 & Grade 3 \\
\hline 1. Intensity of Pain & 0 (No Pain) & 1-3(Mild Pain) & 4-6(Moderate Pain) & 7-10(Severe Pain) \\
\hline 2. Duration of Pain & No pain & $\begin{array}{l}\text { Pain continues } \\
\text { for up to } 24 \mathrm{hrs} \text {. }\end{array}$ & $\begin{array}{l}\text { Pain continues for } 24 \\
\text { to }<48 \mathrm{hrs} \text {. }\end{array}$ & $\begin{array}{l}\text { Pain continues for } 48 \mathrm{hrs} \text {. to } \\
<72 \mathrm{hrs} \text {. }\end{array}$ \\
\hline $\begin{array}{l}\text { 3. Site of Pain (Lower abdo- } \\
\text { men pain, Back pain, pain } \\
\text { radiating to the thigh }\end{array}$ & No pain & $\begin{array}{l}\text { Presence of low- } \\
\text { er abdomen pain }\end{array}$ & $\begin{array}{l}\text { Presence of lower } \\
\text { abdomen pain and } \\
\text { back pain. }\end{array}$ & $\begin{array}{l}\text { Presence of lower abdomen } \\
\text { pain and back pain and pain } \\
\text { radiating to the thigh }\end{array}$ \\
\hline 4. Nature of Pain & No pain & Occasional pain & Intermittent pain & Continuous pain \\
\hline 5. Menstrual flow duration & 3-4 days & 5-6 days & $7-8$ days & More than 8 days \\
\hline 6. Associated complaints & $\begin{array}{l}\text { No com- } \\
\text { plaints }\end{array}$ & 1-3 complaints & & \\
\hline
\end{tabular}

Overall Assessment: The total effect of the therapy was assessed considering the overall improvement in signs and symptoms.

Marked Improvement-65\% (13 patients) in Group A and 50\% (10 Patients) in Group B relief in signs and symptoms.

Moderate Improvement-30 \% (6 patients) in Group A and $40 \%$ (8 patients) in Group B relief in signs and symptoms.

Results:

Table 3: Showing Overall Result of Group A \& B after Treatment

Overall Result after Treatment

\begin{tabular}{|l|l|l|l|l|l|l|l|}
\hline \multirow{2}{*}{ Parameters } & \multicolumn{2}{|l|}{ Group A } & \multicolumn{2}{l|}{ Group B } & \multicolumn{2}{l|}{ Comparative } \\
\cline { 2 - 9 } & Mean & $\mathbf{\pm S D}$ & P-Value & Mean & $\mathbf{\pm S D}$ & P & P-Value \\
\hline Pain Intensity & 0.80 & 0.523 & $<0.001$ & 0.65 & 0.489 & $<0.001$ & $>0.05$ \\
\hline Pain Duration & 0.75 & 0.444 & $<0.001$ & 0.65 & 0.489 & $<0.001$ & $>0.05$ \\
\hline Site of Pain & 0.75 & 0.444 & $<0.001$ & 0.75 & 0.639 & $<0.001$ & $>0.05$ \\
\hline Nature of Pain & 0.80 & 0.523 & $<0.001$ & 0.70 & 0.571 & $<0.001$ & $>0.05$ \\
\hline Menstrual flow Duration & 0.35 & 0.489 & $<0.001$ & 0.50 & 0.607 & $<0.001$ & $>0.05$ \\
\hline $\begin{array}{l}\text { Changes In Associated } \\
\text { Complaints }\end{array}$ & 0.40 & 0.503 & $<0.001$ & 0.45 & 0.510 & $<0.001$ & $>0.05$ \\
\hline
\end{tabular}

Mild Improvement $-5 \%$ (1 patient) in Group A and $10 \%$ ( 2 patients) in Group B relief in signs and symptoms.

Statistical analysis: The data generated was Statistically Analyzed by using Anova Test within the Group and the Mann-Whitney $U$ test between the groups. Where conceded at the level of $p<0.001$ as highly significant, $p<0.05$ as significant and $p>0.05$ was taken as statistically insignificant to carry out the results. 
Table 4: Showing Overall Result of Group A \& B after Follow- Up

\begin{tabular}{|c|c|c|c|c|c|c|c|}
\hline \multicolumn{8}{|l|}{ Overall Result after Follow-Up } \\
\hline \multirow{2}{*}{ Parameters } & \multicolumn{3}{|c|}{ Group A } & \multicolumn{3}{|c|}{ Group B } & \multirow{2}{*}{$\begin{array}{l}\text { Comparative } \\
\text { P-Value }\end{array}$} \\
\hline & Mean & \pm SD & P-Value & Mean & \pm SD & $\mathbf{P}$ & \\
\hline Pain Intensity & 0.35 & 0.489 & $<0.001$ & 0.50 & 0.513 & $<0.001$ & $>0.05$ \\
\hline Pain Duration & 0.35 & 0.489 & $<0.001$ & 0.50 & 0.513 & $<0.001$ & $>0.05$ \\
\hline Site of Pain & 0.35 & 0.489 & $<0.001$ & 0.50 & 0.513 & $<0.001$ & $>0.05$ \\
\hline Nature of Pain & 0.35 & 0.489 & $<0.001$ & 0.50 & 0.513 & $<0.001$ & $>0.05$ \\
\hline Menstrual flow Duration & 0.25 & 0.444 & $<0.001$ & 0.40 & 0.503 & $<0.001$ & $>0.05$ \\
\hline Changes In Associated Complaints & 0.25 & 0.444 & $<0.001$ & 0.35 & 0.489 & $<0.001$ & $>0.05$ \\
\hline
\end{tabular}

\section{DISCUSSION}

\section{Discussion on the selection of Problem}

Dysmenorrhea has high a highly variable prevalence ranging from 45 to $93 \%$ of women of reproductive age. ${ }^{7}$ As menstrual pain is considered a normal part of the menstrual cycle and generally tolerated, and women do not report it. The available treatment modalities for the management of Dysmenorrhea include non-steroidal anti-inflammatory drugs, Oral contraceptive agents and progestins with limited success in combating the disorder completely. It is therefore needed of the hour to develop an Ayurvedic treatment modality that can effectively control and prevent the sign and symptoms, complications associated with Dysmenorrhea along with optimizing women health. The ayurvedic approach differs from the conventional medical approach which targets only pain and sees ovulation as a cause of the pain. Ayurveda addresses the subtle and holistic mechanisms of digestion, metabolism, formation of the menstrual fluid and process of its expulsion which all are interconnected and can create an inflammatory environment in which pain is manifested. Thus, the focus of Ayurvedic management of Dysmenorrhea is to correct Agni, neutralization of Ama leading to the formation of Shuddha Artava which is easy to be expelled from the unobstructed channels by the coordinated activity of Vayu.

\section{Discussion on Drug Review}

Mode of Action of Kumarika Vati: Kumarika vati contains Kumari (Musbbar), Ahifena (Khasakhasa), Agastya twak, Kasis bhasm, Vanga bhasm.

Rasa Panchaka: Rasa- Tikta, Kashaya, Madhura, Amla Rasa. Guna- Laghu, Ruksha, Snigdha, Guru.
Virya-most of the drugs have Ushna Virya Vipakamost of the drugs have katu vipak.

It is having the property of Agnivardhaka because of tikta rasa, ushna virya and katu Vipak. These properties improve digestion as their Agnidipana leads to uttarottara dahtu poshana whereby aartava being updhatu of rasa is optimally formed. Udavartini yonivyapad is because of arrhythmic uterine contraction and upward movement of artava and artava munchana is painful, because of this Kumarika vati having ushna virya, katu vipaka makes the clots liquefied and by this expulsion of artava is painless. Ushna virya is having Vata Kapha hara, raktavardhaka and Agnivardhaka properties. ${ }^{8,9}$

\section{Individual Properties of Drug:}

Kumari (musbbar) has Katu rasa, tikshna, laghu, ruksha guna, ushna virya, katu vipaka and karmakapha vata samaka. It contains anthraquinones and related compounds such as barbaloin and aloeemodin in sufficient quantities to act as false substrate inhibitors blocking prostaglandin synthesis as they have a similar chemical structure to prostaglandin substrates. ${ }^{8}$

Ahiphena Beeja (Khashkhash) due to the ethical issue of the availability of Ahiphen, Khaskhas was taken for preparation of Kumarika Vati. It also has tikta, kashaya rasa, laghu, ruksha guna, Vipaka-katu, Virya- Ushna, kapha vata samaka and analgesic properties. ${ }^{10}$

Agastya Twak has Tikta rasa, Guna-ruksha, laghu, Vipak-Katu, Virya- sheeta. Tikta rasa has the property of lekhana, kanta sodhana. It helps to reverse the pathophysiology of udavartini yoni vyapad as it is 
having the properties of analgesic and antiinflammatory. ${ }^{8,9}$

Kasis bhasma has Vatakapha samaka, Tikta, Amla, Kashaya rasa, katu vipaka, Ushna virya and Artavajanana properties. It is having a property of Rakta Dhatu Vriddhi which improves the uterine blood circulation (reduced blood circulation is a cause for dysmenorrheal). ${ }^{11}$

Vanga bhasma has Tikta, kashaya rasa, ruksha guna. Tikta rasa has property of deepana, pachana. Ruksha guna normalizes the kapha. Vangabhasma has rasayana properties that give strength to uterine muscles by decreasing pain during dysmenorrhea. ${ }^{12}$ In Kumarika vati most of drugs have ushna veerya, katu vipaka, tikta kashaya rasa, ruksha guna. Ruksha guna normalizes the kapha, tikta rasa of drug clear the shrotovarodha. Katuvipaka and ushna virya pacify the vata and it has vatanulomana property which helps in normalizing the function of Apanvayu. In udavartini there is urdhvagamana of rajas. Normal downward movement of rajas is obstructed, and it moves in the reverse direction. Udavartha yonivyapad means painful menstruation in which yo$n i$ discharges frothy menstrual blood with difficulty. Relief of pain is obtained immediately after the proper discharge of menstrual flow. The whole mechanism depends upon the proper functioning of Apana and Vyana vayu where in apana vayu is responsible for Raja pravritti while Vyana Vayu is accountable for blood circulation. This Kumarika vati helps to normalize the vata and kapha which is responsible for udavartini yoni vyapad.

Mefenamic Acid: It is an analgesic, anti-pyretic and weaker anti-inflammatory drug which inhibits COX as well as antagonizes certain actions of PG's. This is an anthranilic acid derivative useful in chronic and dull aching pains. Mechanism of action:

Involvement of $\mathrm{PG}_{\mathrm{S}}$ in dysmenorrheal has been Cleary demonstrated level of $\mathrm{PG}_{\mathrm{S}}$ in menstrual flow, endometrial biopsy, and that of $\mathrm{PGF}_{2 a l p h a}$ metabolite in circulation are raised in dysmenorrhoeic women. Intermittent ischemia of the myometrium is probably responsible for menstrual cramps. Mefenamic acid lower uterine PG levels-afford excellent relief in 60-
$70 \%$ and partial relief in remaining. Ancillary symptoms of headache, muscle ache and nausea are also relieved. Excess flow may be normalized. ${ }^{13}$

\section{Discussion on Results}

Discussion on Pain Intensity

Within the group discussion on the Pain Intensity parameter:

After treatment in group $\mathrm{A}$, the mean value reduced from 2.05 to 0.80 , which means the pain intensity was decreased by $61 \%$, wherein in group B it reduced from 2.20 to 0.65 , which means the pain intensity decreased by $70.5 \%$. After following up in group A, the mean value reduced from 2.05 to 0.35 , which means the pain intensity decreased by $82.9 \%$, whereas in group B, it was reduced from 2.20 to 0.50 , which means the pain intensity was decreased by $77.3 \%$.

Interpretation- This shows there was a decrease in pain intensity after treatment in the group which still decreases till the follow-up.

\section{Between the group discussion on Pain Intensity parameter:}

After treatment in group A, the mean value was 0.80 , but in group $\mathrm{B}$, it was 0.65 , but after follow up the mean value in group A was 0.35 whereas in group B it was 0.50 that result shows an insignificant result at $\mathrm{p}>0.05$.

Interpretation- This shows the treatment was highly significant within the groups and insignificant between the groups. It means the treatment was highly potent in both the groups and both are equally potent to reduce pain intensity. But based on Mann Whitney ranks group A is better than group B.

\section{Discussion on Pain Duration}

Within the group discussion on the Pain Duration parameter:

After treatment in group A the mean value reduced from 1.30 to 0.75 , which means the pain duration was decreased by $42.3 \%$, wherein in group B it reduced from 1.35 to 0.65 , which means the pain duration decreased by $51.9 \%$.

After follow up in group A, the mean value reduced from 1.30 to 0.35 , which means the pain duration decreased by $73.1 \%$, whereas, in group B, it was re- 
duced from 1.35 to 0.50 , which means the pain duration was decreased by $63 \%$.

Interpretation- this shows there was a decrease in pain duration after treatment in both groups, which still decreases till the follow-up.

Between the group discussion on Pain Duration parameter:

After treatment in group A, the mean value was 0.75 , but in group B it was 0.65 , but after follow up the mean value in group $\mathrm{A}$, was 0.35 whereas in group $\mathrm{B}$ it was 0.50 , that result shows the insignificant result at $\mathrm{p}>0.05$.

Interpretation- This shows the treatment was highly significant within the groups and insignificant between the groups. It means the treatment was highly potent in both the groups and both are equally potent to reduce pain duration. But the basis of Mann Whitney ranks group A is better than group B.

\section{Discussion on Site of Pain}

Within the group discussion on Site of Pain parameter:

After treatment in group A the mean value reduced from 2.10 to 0.75 , which means the site of pain was decreased by $64.3 \%$, wherein in group B, it reduced from 2.25 to 0.75 , which means the site of pain decreased by $66.7 \%$.

After follow up in group A the mean value reduced from 2.10 to 0.35 , which means the site of pain decreased by $83.3 \%$ whereas in group B it was reduced from 2.25 to 0.50 , which means the site of pain was decreased by $77.8 \%$.

Interpretation- This shows there was a decrease in the site of pain after the treatment in the group which still decreases till the follow-up.

Between the group discussion on Site of Pain parameter:

After treatment in group A, the mean value was 0.75 , but in group B it was 0.75 , but after follow up the mean value in group A, was 0.35 whereas in group B it was 0.50 that result shows an insignificant result at $\mathrm{p}>0.05$.

Interpretation- This shows, the treatment was highly significant within the groups and insignificant between the groups. It means the treatment was highly potent in both the groups and both are equally potent to reduce the site of pain. But the basis of Mann Whitney ranks group A is better than group B.

\section{Discussion on Nature of Pain}

Within the group discussion on the Nature of Pain parameter:

After treatment in group A the mean value reduced from 2.40 to 0.80 , which means the nature of pain was decreased by $66.7 \%$, wherein in group B it reduced from 2.45 to 0.70 , which means the nature of pain decreased by $71.4 \%$. After follow up in group A the mean value reduced from 2.40 to 0.35 , which means the pain duration decreased by $85.4 \%$, whereas in group B it was reduced from 2.45 to 0.50 , which means the nature of pain was decreased by $79.6 \%$.

Interpretation- this shows there was a decrease in pain after the treatment in both groups, which still decreases till the follow-up.

Between the group discussion on Nature of Pain parameter: After treatment in group $A$ the mean value was 0.80 , but in group B it was 0.70 , but after follow up the mean value in group A was 0.35 whereas in group B it was 0.50 , that result shows the insignificant result at $\mathrm{p}>0.05$.

Interpretation- This shows the treatment was highly significant within the groups and insignificant between the groups. It means the treatment was highly potent in both the groups and both are equally potent to reduce the nature of pain. But the basis of Mann Whitney ranks group A is better than group B.

\section{Discussion on Menstrual Flow Duration}

Within the group discussion on Menstrual Flow Duration parameter:

After treatment in group A the mean value reduced from 0.85 to 0.35 , which means the menstrual flow duration was decreased by $58.8 \%$, wherein in group $\mathrm{B}$ it reduced from 0.80 to 0.50 , which means the menstrual flow duration decreased by $37.5 \%$. After follow up in group A the mean value reduced from 0.85 to 0.25 , which means the menstrual flow duration decreased by $70.6 \%$, whereas in group $\mathrm{B}$, it was reduced from 0.80 to 0.40 , which means the menstrual flow duration was decreased by $50 \%$. 
Interpretation- this shows there was a decrease in menstrual flow duration after treatment in both groups, which still decreases till the follow-up.

\section{Between the group discussion on Menstrual Flow Duration parameter:}

After treatment in group A, the mean value was 0.35 , but in group B it was 0.50 , but after follow up the mean value in group A was 0.25 whereas in group B it was 0.40 that result shows an insignificant result at $\mathrm{p}>0.05$.

Interpretation- This shows the treatment was highly significant within the groups and insignificant between the groups. It means the treatment was highly potent in both the groups and both are equally potent to reduce menstrual flow duration. But the basis of Mann Whitney ranks group A is better than group B.

\section{Discussion on Associated Complaints}

Within the group discussion on Associated Complaints parameter:

After treatment in group A the mean value reduced from 1.00 to 0.40 , which means the associated complaints was decreased by $60 \%$, wherein in group B it reduced from 1.00 to 0.45 , which means the associated complaints decreased by $55 \%$.

After follow up in group A the mean value reduced from 1.00 to 0.25 , which means the associated complaints decrease by $75 \%$, whereas in group B it was reduced from 1.00 to 0.35 , which means the associated complaints was decreased by $65 \%$.

Interpretation- this shows there was a decrease in associated complaints after treatment in the group which still decreases till the follow-up.

Between the group discussion on Associated Complaints parameter:

After treatment in group A, the mean value was 0.40 but in group B it was 0.45 but after follow up the mean value in group A was 0.25 whereas in group B it was 0.35 that result shows the insignificant result at $\mathrm{p}>0.05$.

Interpretation- This shows the treatment was highly significant within the groups and insignificant between the groups. It means the treatment was highly potent in both the groups and both are equally potent to reduce associated complaints. But the basis of Mann Whitney ranks group A is better than group B.

Special Observation: Some patients complained that after taking Kumarika Vati amount of menstrual cycle bleeding and duration of bleeding has reduced as compared to their previous menstrual cycle bleeding. So, this Kumarika Vati can take for further study in diseases like Asrigdara (DUB)

\section{CONCLUSION}

Ayurveda being a holistic medicine offers potential remedies which are proved beyond doubt in solving the problem successfully. Udavartini yonivyapad which has been described in our ancient Ayurveda matches all the symptoms of dysmenorrhea. As the Acharya has mentioned pain during menstruation get immediately relived after menstrual blood discharge resembles spasmodic dysmenorrheal. Discharge of clotted blood mentioned by Indu matches with a special form of spasmodic dysmenorrheal characterized by the expulsion of big blood clots. According to Ayurveda, Aartava or menstruation is a phenomenon, which is controlled and governed by Vata and specifically the Apana vayu, the subtype of the Vata dosha. Due to the suppression of natural urges their vitiation of Apana Vata and this vitiated Apana Vata moves upward which is against Prakrut avastha. This is Urdhva gamana of Rajas hence it means that Udavartini aggravated Apana vayu moves in the Urdhva gati and they're by this viloma gati of vayu causes clist or toda during aartava munchna and the pain subside patients feel comfortable after Artava munchana. Acharya Charaka says that during normal menstruation pain should not be present, so the pain during menstruation is abnormal and hence it should be cured. In the present clinical case, the patient's Agni is in a depleted condition causing Dosha equity, especially Apana vata. Here the main treatment plan should be aimed toward correction of Anuloma gati of vata. Kumarika vati is used 5 days before menstruation as it has deepan, pachana properties and 5 days during menstruation has Vata samak properties. The results show there is significant within the group there for the drug shows improvement in parameters 
before treatment to after follow up and betweengroup comparison shows insignificant differences in both groups in all parameters.

\section{REFERENCES}

1. Bramhanand Tripathi, Charak Samhita, Chaukambha Sansakrit Sansthan, Varanasi, edition 2010, Pg No 78.

2. Nahal Habibi, Mary Soo, Lee Hung, Wan Ying Gan, Rajaji Zulida, Sayyed Morteza Safavi, Prevalence of Primary dysmenorrhea And Factors Associated with Its Intensity Among Undergraduate Student, A CrossSectional Study, https//doi.org/10.1016/j.pmn.2015.07.001.

3. DC Datta, Textbook of Gynecology Including contraceptive, Edited by Hiralal Konar, Jaypee Brothers Medical Publishers (P) Limited, New Delhi, 6th Edition 2013, Pg No178.

4. Shashikalakaranth, S R Liya, Prevalence and Risk Factors for Dysmenorrhea Among Nursing Students and Its Impact on Their Quality of life, International Journal of Reproductive, Contraception, Obstetrics and Gynecology, July 2018, Pg No 2661-2667.

5. Ambika Datta Sastri, Bhaisajya Ratnavali, Choukhambha Surabharati Prakashana, Varanashi, Edition 2014, Pg No 370.

6. Www.Medscape.Com.

7. Bernadi M, Lazzeri L, Perelli F, Reis FM, Petraglia F, Dysmenorrhea and related disorders, 2017 Sep 5, 6:1645, Doi:12688/f1000research, PMID:2894448, PMCID: PMC5585876.

8. P V Sharma, Dravyaguna Vijanana, Chaukhambha Bharti Academy, Varanashi, Vol-II, Reprint- 2009, Pg No- 448/290.

9. Prakash L Hegde, Harini A, Dravyaguna Vijanana, Chaukhambha Sanskrit Sansthan, Varanashi, Vol II, Reprint 2017, Pg No-504/ 4.

10. K C Chunekar, Bhavprakash Nigantu, Shri Bhavmishra Commentary, Chaukhambha Bharti Academy, Varanashi, Reprint- 2010, Pg No-140.

11. Acharya Sri Madhva, Ayurveda Prakash, Edited by Gulraj Sharma, Chaukhambha Bharti Academy, Varanashi, Reprint-2017, Pg No-325.

12. Pandit Kashinath Sastrina, Rastarangini, Chaukhambha Bharti Academy, Varanashi, Reprint-1994, Pg No-443.

13. K D Tripathi, Essentials of Medical Pharmacology, Jaypee Brothers Medical Publishers New Delhi, $8^{\text {th }}$ edition Pg No 211, 218.

\section{Source of Support: Nil \\ Conflict of Interest: None Declared}

How to cite this URL: Rashmi Verma et al: Comparative Clinical Study Of Kumarika Vati And Mefenamic Acid In Udavartini Yonivyapad (Spasmodic Dysmenorrhea). International Ayurvedic Medical Journal \{online\} 2021 \{cited December 2021\} Available from: http://www.iamj.in/posts/images/upload/2933_2941.pdf 